\section{Voice Actresses Rising The Multilayered Stardom of Megumi Ogata in the 1990s}

\author{
Minori Ishida
}

In Japanese discourse, the year I 995 is considered the beginning of the third anime boom, as it has come to be referred to in Japanese discourse, ${ }^{1}$ and this boom took its departure from Neon Genesis Evangelion (EVA). Many critics have attempted to explain what was so innovative about $E V A$, and as this volume also evinces, the issue is still under discussion. But most studies have analyzed EVA's visuals and not paid sufficient attention to its acoustic side. EVA's 'voices' remain underdiscussed, although they have played a crucial role in creating the series' psychologically substantiated characters. In one of the few exceptions, Fang Jin Lee (2010: $24 \mathrm{I}-244$ ) points out that it is the voices that warrant narrative coherence in the 26 th episode of the first anime series. This episode surprised viewers by its unconventional collage of different visual materials, ranging from rough sketches to live-action footage. But even if the visuals appeared chaotic at times, the characters conveyed their thoughts and feelings clearly-by voice. Thanks to the voice acting, even the unusual visuals made sense.

As the 26th episode of EVA demonstrates, the functions of voice should not be underestimated at all; rather, they are necessary factors to establish anime as an audio-visual medium. The voice works on several levels of anime. First, it represents the characters' acoustic appearance. At the same time, the voice helps to create the narrative. In addition, the voice belongs to voice actors and mediates between them and the audience. Voice actors establish their own persona by performing different characters throughout their career. Thus, audiences come to receive a specific voice as connected not only to a character,
I. See Tsugata (20II: 30), Hikawa (2000: I04-105) and Masuda (2007: II9), as well as Kacsuk's chapter in this volume for a survey of the three anime booms.

How to cite this book chapter:

Ishida, M. 202I. Voice Actresses Rising: The Multilayered Stardom of Megumi Ogata in the I990s. In: Santiago Iglesias, J. A. and Soler Baena, A. (Eds.). Anime Studies: Media-Specific Approaches to Neon Genesis Evangelion. Pp. I I I-I 33 Stockholm: Stockholm University Press. DOI: https://doi.org/IO.I6993/bbp.e. License: CC-BY 4.0 
but also to a specific actor. Furthermore, the voice is not limited to a certain character within a certain work.

Pre-existing research on the voice in live-action cinema is helpful for investigating the way in which the voice works in anime, from production to reception. Discussing the talkies, film scholar Mary Ann Doane defined "the body reconstituted by the technology and practices of the cinema" as "a fantasmatic body, which offers a support as well as a point of identification for the subject addressed by the film" (1985: 162; emphasis in the original). According to Doane, "the voice serves as a support for the spectator's recognition and his/her identification of, as well as with, the star" (I985: I64). The voice in anime shares many functions with the one in the talkies. However, because the audience does not see the face and body of the voice actors performing the characters, the characters in anime have more "fantasmatic" bodies compared to live-action cinema, and the voice actors reconstitute them in more complicated and innovative ways.

This chapter aims to reconsider the way in which voice and voice acting developed in EVA, focusing on Megumi Ogata, who performed Shinji Ikari, the I4-year-old boy protagonist of the I 995 anime series. Shinji is one of the most fantasmatic bodies among the characters in EVA, because he is performed by a voice actress. However, employing a female performer for the voice of a boy character in anime was not innovative in itself, as there was already such a tradition in place. In the first TV anime series of the 30-minute weekly format, Tetsuwan Atomu (Astro Boy, I963-66), a 26-year-old theater actress, Mari Shimizu, played the eponymous robot. Thereafter, many boy characters performed by voice actresses appeared both in anime for the whole family and in anime specifically targeted to otaku fans. To name just a few, they included Nobita in Doraemon, voiced by Yoshiko Ōta in I973, Noriko Ohara from I979 to 2005 and Megumi Ōhara since 2005; Son Gokū voiced by Masako Nozawa 
in the Dragon Ball series (I986-2018); Luffy by Mayumi Tanaka in One Piece (since I999); and Loran by Romi Park in Turn a Gundam (1999-2000).

Interestingly, this casting convention was a by-product of the Japanese Child Welfare Act and Labor Standards Act, both enacted in I947. In line with Japan's democratization after World War II, these acts were aimed at securing children's rights and protecting them from labor exploitation, with strict regulations for minors (i.e., persons under the age of 18 ), which included the prohibition of children from working past $8 \mathrm{pm}$. Hence, child actors were not allowed to participate in night-time recordings or film shootings, ${ }^{2}$ and when going through compulsory education, school days were to be avoided whenever possible. Thus, in the late I940s, adult voice actresses came to play child characters in radio dramas and TV puppet plays produced by NHK (Nippon Hosō Kyōkai, the Japan Broadcasting Corporation), as well as TV animation and live-action TV dramas imported from the United States. From 1953, when TV broadcasting began, until the mid-I96os, the broadcasting was live. ${ }^{3}$ Because of both the children's labor regulation and the technological limit of live broadcasting, actresses were employed for child characters of both sexes. One of them was Masako Nozawa, who began to voice boy roles in the I950s (Nozawa \& Hirano 2016). Voice actresses can easily pass as boys, unless they show their faces and bodies to the audience. Anime, that is, animated TV series produced in Japan starting with Astro Boy in 1963, inherited the discrepancy between voice and character in terms of age and sex from previous radio drama and developed it into one of its outstanding characteristics. In the United States, especially in Disney's feature-length animations, boy characters have been performed by boy actors such as young Bambi by 6-year-old Donnie Dunagan in Bambi (1942). This fact shows that the US casting of voice actors has been based on similarities of sex and age.
2. Kikuko Kinoshita, who began to play child roles of both sexes in 1948 as a member of the voice actors' section of TV station NHK (Tokyo Hosō Gekidan), stated in an interview with the author on 7 December 2016 that the officers of the CIE (Civil Information and Educational Section), a section of the General Headquarters for the Allied Powers, ensured that there were no child actors on the set after $8 \mathrm{pm}$.

3. The four-head video-tape recorder for TV broadcasting was invented by Ampex in the United States in 1956; in I959, Japanese companies succeeded in its domestic production. By the midI960s, it had spread to all Japanese TV broadcast stations as standard equipment (Kawamura 200I: 8-9). 
Recently, there is an increasing critical interest in voice acting and voice actors in Japanese-language Anime Studies. Shō Kobayashi (2015) and Ryōta Fujitsu (2018) provide general histories of voice actors, pointing out how they differ from performers on radio and $\mathrm{TV}$, as well as in cinema. However, their investigations do not focus on the convention of casting voice actresses as boy characters, and neither does Jin's analysis (2010). ${ }^{4}$ The issue of those voice actresses is closely related to the social and cultural history by which anime has been shaped. Moreover, taking the issue seriously leads us to rethink anime as an audio-visual medium and focus on its specificity in comparison to other similar media. This is why I am discussing the acoustic achievements of EVA on the example of Ogata performing the role of Shinji. As mentioned above, casting Ogata for that role was part of anime conventions. But her actual performance was qualitatively unprecedented in anime history, in particular within the context of the I990s, when it became usual for voice performers to gain stardom by disclosing their face and body.

My discussion below foregrounds performers and paratextual materials: it considers Shinji's voice in dubbed versions of EVA, Ogata's performance of characters in other anime series and articles on Ogata in magazines specializing in anime. This approach will serve to analyze voices objectively in view of the methodological issue that sound in non-visual narratives such as radio drama shows "the heavy reliance on the cultural connotation" (Hill 200I: I09) and the interpretation of voices is inclined to be highly subjective. First, I analyze how Ogata's performance as Shinji was received by the South Korean audience in comparison of the Japanese original to the Korean-

4. In English language anime studies, Rayna Denison discusses voice actresses performing boy characters, focusing on Romi Park and Rie Kugimiya in the Fullmetal Alchemist series (2003-II) (20I7: IOI-II7). dubbed counterpart. Although both voiced by actresses, the performances were significantly different due to the status of anime and of voice actors in both Japan and South Korea in the I990s. Second, I investigate the representation of Ogata's body in an anime magazine, Animage, focusing on the interrelationship between Ogata and her 
audience pertaining to the two characters she played before Shinji. Correlated with the characters she performed, her visual appearance changed considerably between I992 and I995. Third, I show how Ogata's performance as Shinji extended the convention of casting voice actresses to perform boys' voices in anime, and I illuminate this extension in detail on the example of Ogata's voice performance in the animated feature film The End of Evangelion (1997).

\section{The Sombre and Sexy Voice of Shinji: Differences from the Korean-Dubbed Version}

Shinji, the protagonist in EVA, is a troubled boy. He has been abandoned by his father for many years, but he is then suddenly called in by him to pilot the Eva unit. Shinji is forced to fight with enigmatic enemies called Angels to save the world without even knowing what he is doing. Throughout the narrative, he is troubled by his relationship with the people surrounding him, including his father, Gendō, and his peer pilots Rei, Asuka and Kaworu. Moreover, he is repeatedly injured in battle. In short, Shinji is far from the heroes of generic robot anime; rather, he is a miserable child, neglected by his father and sometimes even abused. Ogata expresses the vulnerability of his body and soul using a sombre voice, which made Shinji stand out among other boy characters played by voice actresses up until that point.

For an analysis of Ogata's performance, the Korean-dubbed version of EVA provides some interesting insights. In I996, Champ, a label run by the South Korean animation production company and distributor Daewon Media, launched EVA on VHS. In this localized version, South Korean performers voiced the characters, and the Korean casting shared the Japanese convention of voice actresses playing the roles of boys, by employing Gyeong Jin An to perform Shinji. In contrast, in the North American, South American and European dubbed versions, Shinji's voice was performed by male voice actors: 
5. Regarding the information on Mongillo and Lucindo, see https://www. huffpost.com/entry/shes-changing-the -game-ca_b_8I930I4 and https://tvtropes .org/pmwiki/pmwiki.php/Trivia/Neon GenesisEvangelion.

6. Personal interview with the author on 25 November 2018.

7. Ibid.
Shinji was dubbed by Spike Spencer in the English version, Albert Trifol Segarra in the European-Spanish version, Victor Ugarte in the Mexican-Spanish version, Donald Reginoux in the French version, Hannes Mauver in the German version and Fábio Lucindo in the Brazilian-Portuguese version. Interestingly, only Lucindo was I 5 years old, while the others were adults. In 2019, Netflix launched a new English-dubbed version, and Casey Mongillo, a transgender voice actor, performed Shinji. ${ }^{5}$ Both the Japanese and the Korean dubbing leaned on actresses, but the two versions of Shinji differed significantly. Ogata's pitch is lower and huskier in tone than An's. As a result, An's Shinji sounds more childlike and innocent. A South Korean female viewer evaluated the two performances as follows:

Shinji's voice performed by Ogata is a thousand times sexier than An's. I was especially stunned by the screams when he was wounded. Ogata's shouts seemed to stem from deep agony and grief, not simply from physical injury. ${ }^{6}$

The viewer also considered reasons for the difference between the two versions of Shinji:

Undoubtedly, An is an equally talented and skillful voice actress. So, I believe that the Japanese and the Korean versions differed not merely due to technical matters. Rather, An's performance of innocence may have been influenced by the understanding of anime in South Korean society, which was different from that in Japan. South Korean society was not familiar with the concept of a young-adult audience taking anime seriously and thinking deeply about characters and stories. ${ }^{7}$

To understand her comments more precisely, it is useful to consider how the opening song of EVA was modified in the localization process. Although the 1996 Korean version adopted the Japanese song, Zankoku na tenshi no tēze (A Cruel Angel's Thesis), the lyrics and the visuals were changed completely. The Japanese version starts with the line "Zankoku na tenshi no yō ni, shōnen yo, shinwa ni nare," which 
translates into English as "Young boy, like a cruel angel's thesis, live up to be a legend" (A.D. Vision, I997), or "Like a cruel angel, become a legend, young boy" (Netflix, 2019). However, in Korean, "cruel" was replaced by "brave," and words that manifest a clear dichotomy between good and evil, such as "justice" and "hero," were added, words that can be traced back to the opening songs of classic robot anime series of the I960s and the I970s: Tetsujin 28-go (Iron Man No. 28, or Gigantor, I963), Majingā Zetto (Mazinger Z, I972) and Gettā Robo (Getter Robo, 1974). And it is precisely this connotation that reveals the Korean distributor's marketing strategy, namely, to categorize EVA as a title aimed at children. The re-edited visuals of the opening reinforce that orientation: Shots from the Japanese opening and from some of the episodes were conjoined and female nudes removed (which in the Japanese version appear only as a silhouette, but with an emphasized outline of the bust).

In contrast to South Korea, anime audiences in I990s Japan included a considerable number of young adults. The coming of age of anime as a young-adult media was epitomized by Uchu senkan Yamato (Space Battleship Yamato). In March 1975, the TV series which had started the previous year was cancelled due to low audience ratings, but dedicated viewers in their late teens to early $20 \mathrm{~s}$ achieved a re-broadcast by sending letters to the production company and TV stations. And when an animated feature film of Space Battleship Yamato was produced in 1977, it became a huge box office hit. Thus, Space Battleship Yamato made visible young adult audiences' serious and strong interest in anime. ${ }^{8}$ From then on, they became a constant factor for anime productions to reckon with, and they led to intricate narratives with detailed settings and psychologically substantiated characters. This was the context in which EVA and, with it, Shinji emerged. I now proceed to analyze in detail how voice actors accommodated young adult viewers' expectations, and how they refined their craft.
8. On the campaigns by the young adult audience, see Nakatani (I982), as well as Nakatani and Kushino (1982). 


\section{Voice Actors as Stars and the Impact of Anime Magazines}

In cinema, TV drama and theater, the term star is used to indicate a privileged actor or actress who has a personality that extends beyond the characters he or she plays. I call this personality "star persona." "The visibility of a star's face and body is vital for their star persona in cinema, TV drama and theater. In contrast to those media forms, the faces and bodies of voice actors remain invisible when performing characters in anime. More importantly, the criteria for casting them are not necessarily based on their visual similarity with the characters they play, since in the process of anime production, the visual and aural tracks of a character are separately created: voice actors bring characters to life with their voices, whereas animators do the same thing with a succession of drawings that are to appear moving when screened. Consequently, anime characters are located in between audio and visual tracks, being split into the two mediums. In the case of a voice actress playing the role of a boy, this splitting becomes quite clear. When Mari Shimizu performed Astro Boy in the early I960s, she was even asked to erase her visual presence in public for maintaining the plausibility of the anime character. When she got pregnant, the discrepancy was heightened, and she tried not to appear in public at all (Shimizu 20I 5: 90). However, in due course, anime matured as entertainment for young adults, and the audience soon became interested in the characters' voices and the voice actors themselves, which again gave rise to a new generation of voice actors. For example, Yōko Asagami, who played Yuki Mori, the heroine in Space Battleship Yamato, had been a big fan of anime and eager to become a voice actress before she actually became one (Kobayashi 20I5: IO-II). This contrasts with the voice actors of previous generations, who

9. Richard Dyer names it "star image," as a set of effects produced by the media including magazines, advertisements and so on (I998: 60-63). began their careers as stage actors in theater. Asagami's case also shows how the cultivation of voice actors in anime became selfsufficient and autonomous. 
In correspondence with the voice actors' new position in the reception of anime, the opportunities to show themselves to the audience increased. Anime magazines played a crucial role in this process. The late I970s, when the popularity of Space Battleship Yamato peaked, saw the launch of the magazines OUT (1977-95), Animec (1978-87) and Animage (since 1978). While editing the first issue of Animage, Toshio Suzuki, the future producer at Studio Ghibli, lent his ear to the potential readership of late-teen anime fans. Suzuki realized that the anime characters were stars or idols for them, and that they wanted to know the creators behind them (Ōtsuka 20I6: I43). Hence, staff interviews became feature articles. Voice actors were no exception, and many articles about them were accompanied by portrait photographs. Due to continued interest, a magazine exclusively on anime voice actors was launched in 1994: Voice Animage, a subsidiary of Animage. Thus, specialized anime magazines made voice actors' visual presence and self-presentation an essential part of the reception of both voice actors themselves and anime as a media form. Audiences began to share performers' star persona and participate in their stardom, going beyond the visual difference between them and their roles. Consequently, stardom shifted from characters to performers.

\section{Ambitious Casting: Ogata as Kurama in Yū Yū Hakusho}

In I992, Ogata debuted in the role of Kurama, a I 5-year-old boy, in Yü Yü Hakusho (I992-95), a TV anime series based on the manga of the same name by Yoshihiro Togashi. At the time, the media facilitating voice actors' stardom were already in place-magazines to begin with. However, for a voice actress playing boy roles, one issue remained, namely, how she could possibly fill the gap between the boy character and herself in terms of visual or bodily appearance. Casting Ogata as Kurama raised many controversies. Ken Hagino, the producer of the anime version of $Y \bar{u} Y \bar{u}$ Hakusho, said that the 
production crew had a long discussion on that issue. According to Hagino, the fans of the original manga expressed their discontent over the choice of Ogata (20II: 308) because Kurama was much older than any other boy character played by a voice actress up until that point. Moreover, Kurama had a delicate and complicated personality with a dark and tragic background, a fox monster in the past and now reborn as a human. His appearance, with long red hair and deep green eyes, was elaborately designed. In the battle scenes, he fights elegantly using even roses as his weapon, and he is often injured and bleeds. In other words, he is mysterious, fragile and sensual.

In retrospect, Ogata herself described the strong pressure she felt. Before she played Kurama, it was rare for a voice actress to play the role of a high-school boy; this happened only once in a special case when Masako Nozawa played Gokū from his childhood to his youth in Dragon Ball. Besides, Kurama is a reserved character and not pushy. Hence, Ogata had to develop a new sensibility for him, which she explained as follows:

I had to give to Kurama as real a presence as the boy characters voiced by male actors. Kurama is not a boy who is surrounded by girls. He always stays behind and pacifies the other boy characters' anger and anxiety. So, if my voice sounded lighter than those of the boy characters played by male actors, Kurama's presence would have been diminished. Performing in a low and suppressed tone requires higher skills than just shouting. I was not sure if I could do this. Fortunately, my vocal cords are tough. But they are completely different from those of male actors. I was suffering. (Ogata I997: 5I; translation by the author)

Clearly, Ogata was in a quandary regarding her ability to perform the part of Kurama. But she succeeded by opting for a lower pitch with a mellow tone in accordance with Kurama's psychological depth and visual appearance. As a result, she was hailed by the audience, especially 


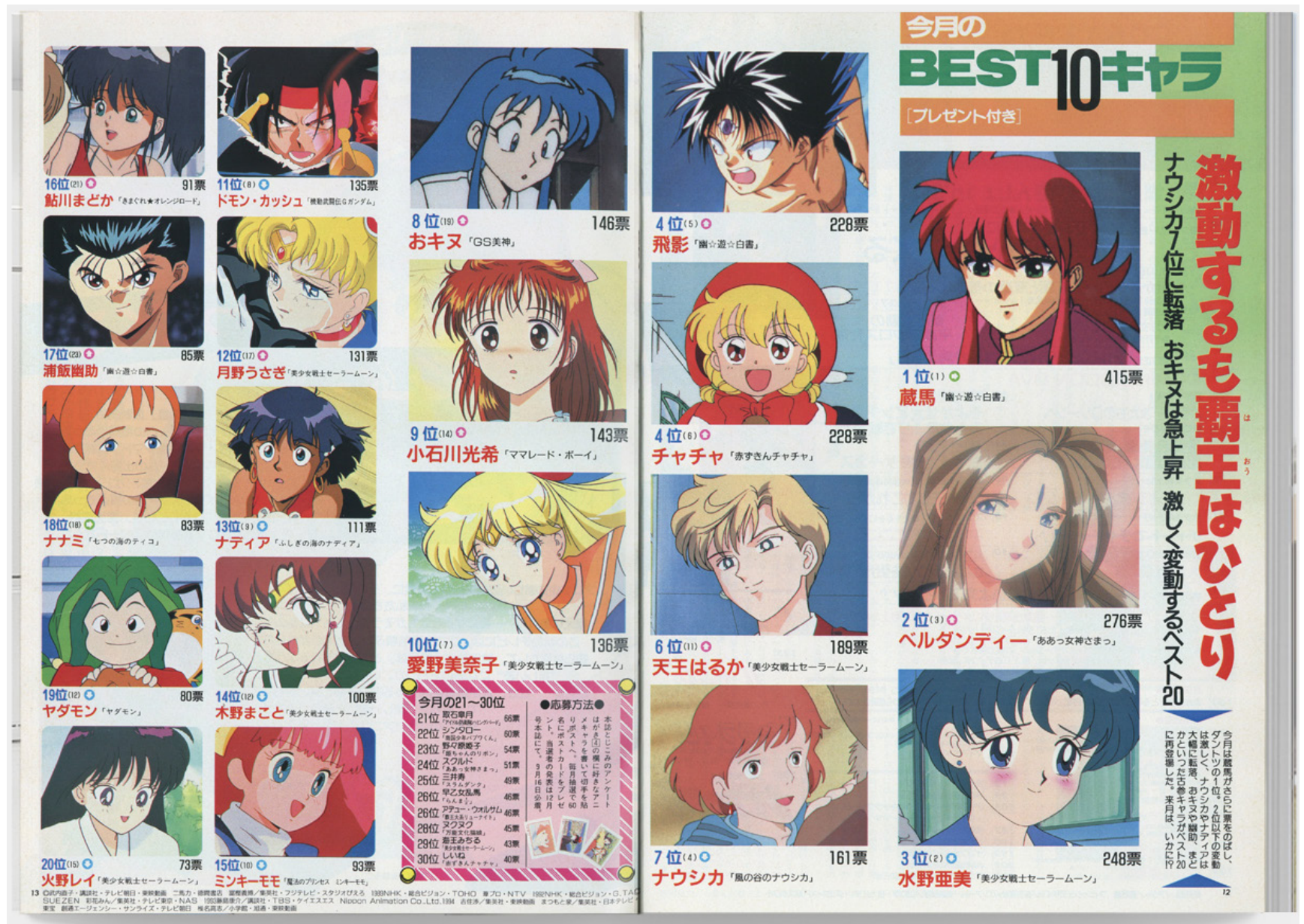

female viewers. In a fan voting for characters by Animage, the anime version of Kurama was rated one of the most popular characters in the I990s (Fig.4.I). ${ }^{10}$

This led to Ogata acquiring star status. Certainly, having Ogata play the role of Kurama followed a convention of anime casting that began with Astro Boy. But, at the same time, Ogata subverted the convention by giving rise to a way of voicing boy characters
Figure 4.1. "Kongetsu no Best Io Kyara” Animage (\#I96). () Tokuma Shoten.

Io. According to the monthly character ranking in Animage, Kurama remained in the top 20 throughout the I990s. 
that differed from previous male performances. Not unlike the stylized masculinity invoked by female impersonators on the Takarazuka stage (which comes to the fore in the following section), Ogata's masculine voice appealed to female audiences, and to male viewers, too.

\section{Not Just Anime: Ogata's Visual Presence in Anime Magazines}

Interestingly, Ogata changed the way in which voice actresses were accepted by the audience, ultimately assuming a star persona. Anime magazines played an important part in this process. In Animage, Ogata first appeared in issue 178 published in April 1993. The article introduced her as a voice actress playing the role of Kurama, and it was accompanied by her picture, as well as a comment that she was training her abdominal muscles for acting in a lower voice. At that time, long-haired, she looked very feminine (Animage I993a: I19). Shortly after that, issue I 86 featured an interview with her. Although again accompanied by a photograph of her with long hair, the headline read "Ogata-san wa seiyūkai no Takarajenne?" (Is Ms. Ogata a Takarasienne among the voice actors)? (Animage I993b: I38), alluding to her performance of Kurama's gender (Fig.4.2).

This headline by an editor was not just a figure of speech, because from then on, the topos of the Takarasienne provided the platform on which Ogata and her fans communicated with one another.

The word Takarasienne refers to a member of the all-female Takarazuka Revue Company which has existed since I9I4. Among these performers, those who play male parts, so-called otokoyaku, are usually most popular with the mainly female fans. Similarly, Ogata playing Kurama gained huge support from female viewers. According to an article in Animage (1993b: I38), 99 percent of her fans were female. The female audience accepted her unhesitatingly, including the difference between female voice actress and male anime character. 


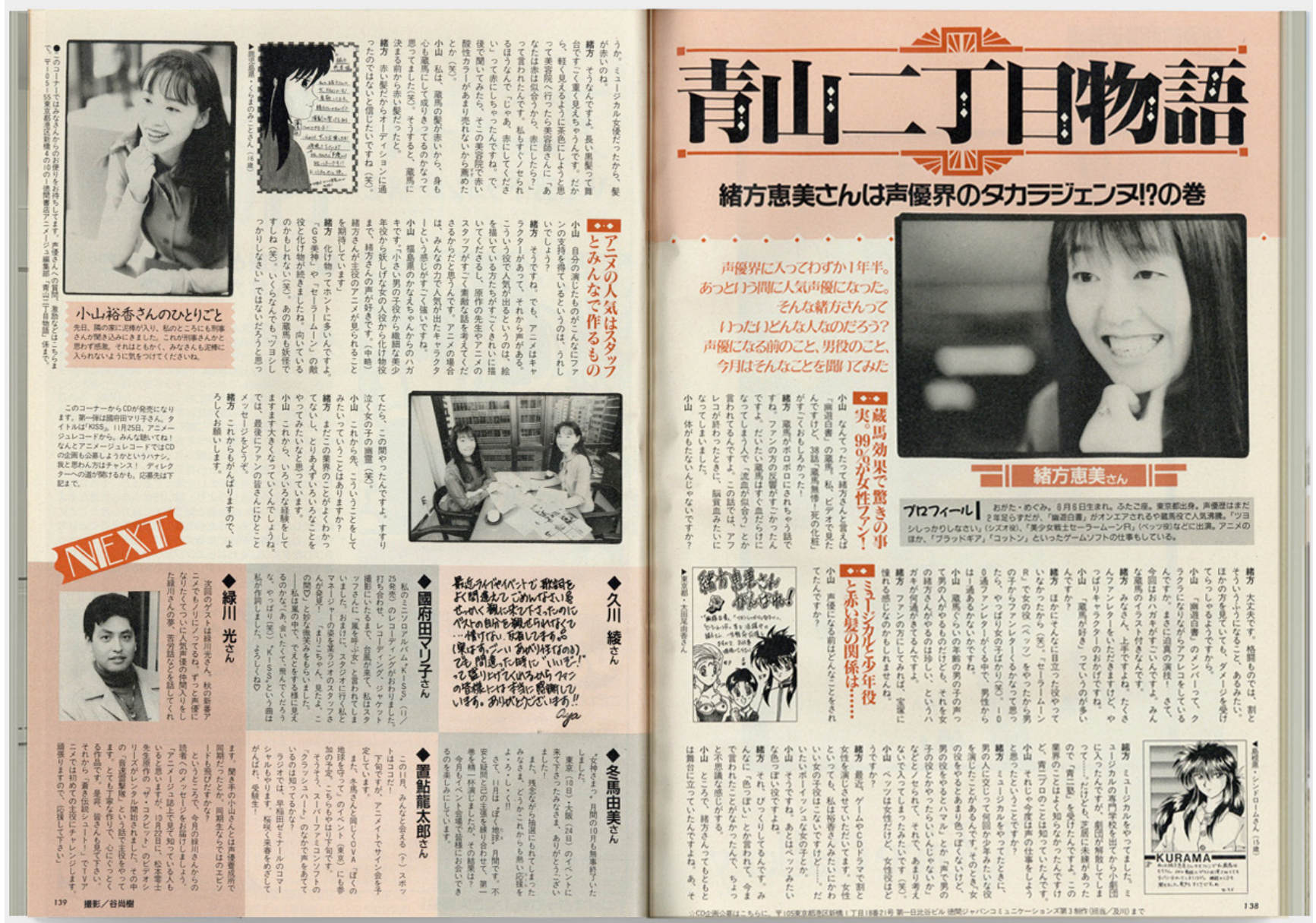

The fans' reception of Ogata as Kurama did not depend on a simple realism that lays emphasis on matching actors and characters in terms of sex and age.

Sociologist Sonoko Azuma's analysis of the relationship between Takarazuka performers and their fans can be helpful in understanding Ogata's reception by female viewers. In the Takarazuka context, fans support male impersonators (otokoyaku) and enjoy their performance of male roles knowingly. Azuma points out that four
Figure 4.2. Animage $\left(\#_{\mathrm{I}} 86\right)$. (C) Tokuma Shoten. 
layers construct the figure of a Takarasienne for the fans: her rolename existence, her stage-name existence, her nickname existence and her real-name existence:

To the audience, the role-name existence is connected to the tale being performed on stage. Similarly, each member of the audience has, to a greater or lesser extent, an image and some kind of story for each of the Takarasienne's four layers in mind. The stage-name existence connotes the performer's special qualities and past roles, as well as the general images of otokoyaku and musumeyaku. ${ }^{11}$ The nickname existence is associated with the character as introduced by the media and other offstage information. Should an audience member imagine a Takarasienne's struggle, such thoughts would concern the real-name existence. (Azuma 2019: 272-273)

Azuma describes how Takarazuka stardom and fandom are created by utilizing these four layers. Each layer is classified according to whether it is internal or external to the play, enacted onstage or offstage, made public to the fans or not. And these layers are interconnected in a multilayered way (Azuma 2019: 272). In the case of a male impersonator, the role-name existence on stage becomes a component of the stage-name existence, reinforcing fans' reception of her as male. At the same time, the nickname existence indicates that she does not deny her offstage gender. Fans participate in this seamless overlapping of the layers, and the fact that the otokoyaku actors do not have male bodies beneath their costumes becomes insignificant. Instead, the central issue is whether they "create their own unique otokoyaku persona" (Azuma 2019: 268).

This analysis of the reception of otokoyaku in the Takarazuka Revue can be applied to understanding the reception of Ogata by the female audience. Moreover, even though Azuma does not refer to stardom itself, her discussion can be stretched to the process in which an actor or actress is received as a star, because the stardom requires the

II. Musumeyaku: female parts and their performer. audience to participate in the network of the four layers highlighted by Azuma. namely that is, a star persona. She neither denied nor erased 
the gap between the two, but utilized it to construct her star image as an effect of interweaving the four layers.

In March 1994, Ogata released her first CD with songs and narration, entitled Half Moon. The CD includes a boy-meets-girl story in which Ogata plays both roles. She had already become adept in playing both girl and boy roles, for example, in Y $\bar{u} Y \bar{u}$ Hakusho, where she also voiced several minor girl characters. In October 1994, Ogata revealed that she wanted to express the two sides of her mind: masculine and feminine (Animage 1994: 64). Her portrait on the CD cover was likely to help fans understand. In her paratextual relation to her audience, she did not hide being female; rather, she deliberately foregrounded it. Apparently, for her, the image of the Takarasienne proved useful as a performative model.

\section{Character Reinforcing the Star Persona: Tenoh Haruka/Sailor Uranus in Sailor Moon S}

Soon after the release of Half Moon, Ogata began to play another role that was to become important for her career, that of Haruka Tenoh, or Sailor Uranus, in Sailor Moon S (1994-95). It brought her an enthusiastic admiration by female fans. ${ }^{12}$ Haruka questions gender and sexuality further: the narrative of the anime defines Haruka's sex as female, and she also self-identifies as female, but she wears male attire and always refers to herself with the male first-person pronoun, boku. Furthermore, she is in a romantic relationship with her female partner, Michiru, or Sailor Neptune. In contrast to the anime, the manga version by Naoko Takeuchi, on which it was based, depicted Haruka/Sailor Uranus as androgynous. There, masculine-clad Haruka uses an even stronger male pronoun, ore (Takeuchi I994a), while Sailor Uranus in her feminine costume uses the female variant atashi (Takeuchi I994b). In the manga, the correspondence between speech and costume stays static, tying the masculine verbal expression with the male costume and vice versa.
I2. In I996, Haruka was seventh in the annual Animage voting by female readers (issue 2 I2), and 93rd in the annual character ranking (Animage, I996). Her popularity was supported by female fans with a deep affection for the character (i.e., moe), which indicates that, in the I990s, moe was not exclusively male. 
Therefore, Haruka never actually disturbs the gender boundary (Ishida 20I9: 30-33). In contrast, the anime version of Haruka/ Uranus is much more provocative, and Ogata's performance accentuated this. Her voice is lower and huskier than the one she used for Kurama and, in battle scenes, when she shouts, it is much stronger. When Haruka transforms into Uranus, her male attire turns into the sailor warrior's costume. As a result, Ogata's powerful masculine voice becomes incongruous with the sailor warrior's feminine costume, the discrepancy between the visual appearance and the voice being much more prominent.

This playful representation of Haruka in the anime attests to the maturation of anime voice acting in the I990s, or to put it another way, the fact that mature audiences were to be addressed, which included an erotic dimension. The role of Haruka also contributed to the development of Ogata's own star persona. Ogata adopted Haruka's features: she cut her hair short and began to wear suits when making public appearances in magazines and at fan meetings and concerts. The new look complied with the stage-names and nicknames of Takarazuka's male impersonators who also keep their hair rather short and wear pants in a masculine style. The most significant among the articles about Ogata is "Ogata to deito" (Going on a date with Ogata), a serial published in Animage in 1995-96 (Animage r996a: 106-107; Animage 1996b) (Fig.4.3).

Ogata entertained one or two female fans on a date, and the magazine reported on this in detail. Ogata herself was always in masculine attire, while the female fans wore dresses, the former and the latter respectively emulating the masculine Haruka and the feminine Michiru in Sailor Moon S. Adopting a behavior that corresponds to Haruka's sexuality, Ogata could make gender/sex fluidity a component of her star persona.

Magazines serve special interests and communities, while newspapers are to provide coverage and primary information to civil society at large. Unlike radio and television, magazines target "small 


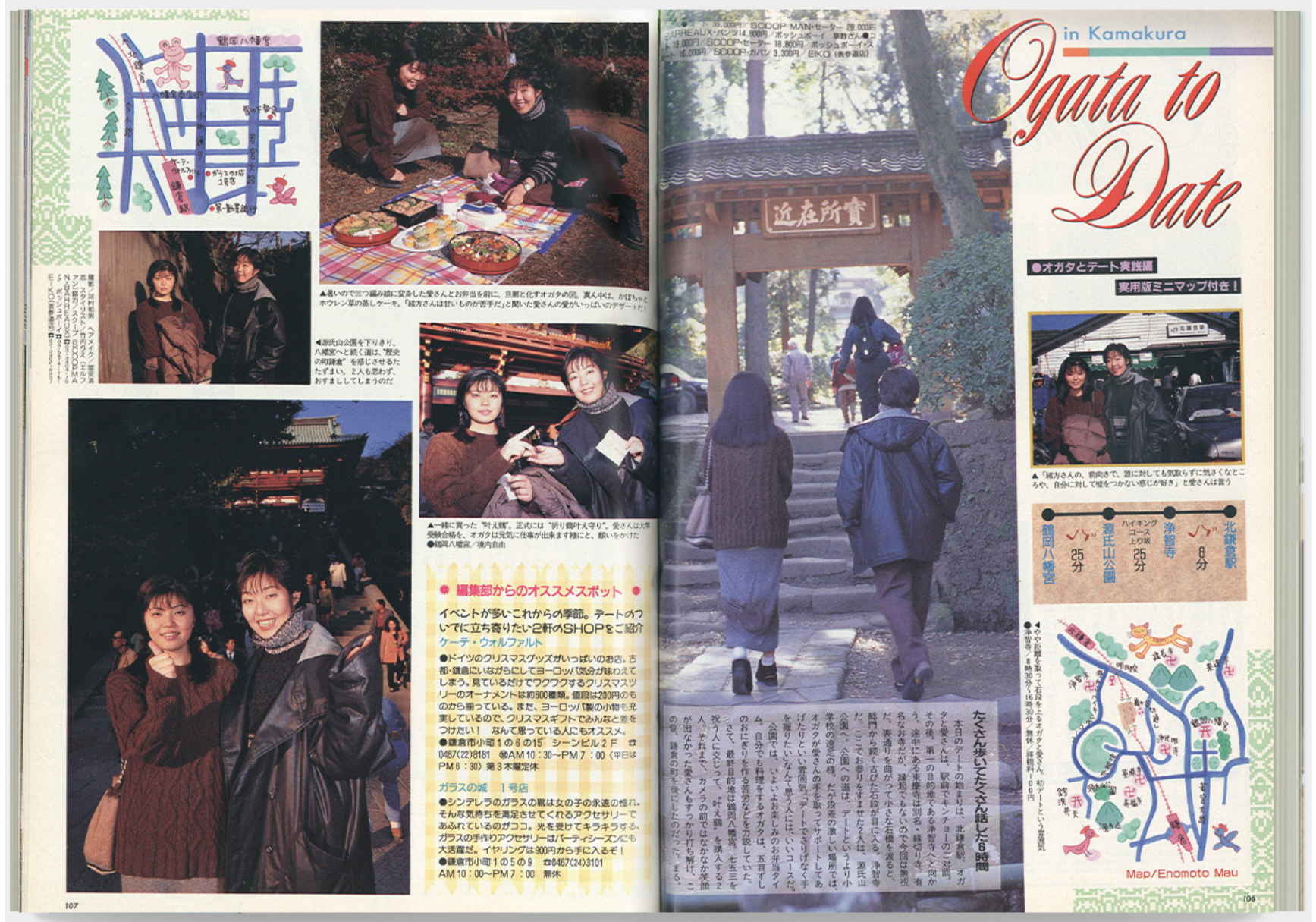

readerships establishing a strong and deep connection" (Yoshida 20I7: I2). Anime magazines were particularly specific since they addressed a youth subculture, and precisely the limitedness of their subject incited readers' active participation. It was this participation by female magazine readers that helped construct Ogata's star persona in correspondence with the characters she voiced. Her fans realized that she and her characters were different. However, as implied by the critical keyword Takarasienne in Ogata's first
Figure 4.3. Animage (\#2II). (C) Tokuma Shoten. 
interview in Animage, fans willingly participated in constructing her star persona, picking up the characters' features ranging from visual appearance to personality and projecting them onto Ogata's body. As "Going on a date with Ogata" suggests, female fans saw her like an otokoyaku in the Takarazuka Revue. Thanks to the interaction with female fans via the anime magazine, Ogata's persona assumed fluidity with regard to gender and sex. Thus, her own sexuality and that of her characters coexisted successfully, along with her own star persona. In summary, the voice actress with the stage-name Megumi Ogata is a construct that emerged from multilayered stardom.

\section{Innovative Performance in The End of Evangelion (1997)}

After establishing her star persona as one of gender/sex fluidity in the performance of Haruka, Ogata returned to a boy role, Shinji. At first glance, Shinji seems to be more conventional than Kurama and Haruka, very much in line with the genre of robot anime. However, he is neither cheerful nor straightforward. On the contrary, he is in conflict with the people around him, including his father, his commander Misato, his companions Rei and Asuka, and hence, the narrative revolves around his suffering and agony. With regard to psychological depth, Shinji belongs to the same category as Kurama and Haruka, and Ogata's performance of him reveals this continuity in terms of tone and pitch.

The second animated feature film, The End of Evangelion, released in the summer of 1997 , is especially significant. This film elaborates on the last two episodes of the initial TV series that went on air without having been completed. Produced to provide a definitive ending, the film addresses sexual issues in an extremely overt way. Ogata strived to act a scene that depicts Shinji's sexual arousal, too. At the beginning, Shinji visits Asuka in hospital. He confesses his fear of Misato 
and Rei, and he repeatedly asks Asuka to help him. However, she is in a coma and cannot respond. Driven by anxiety, he grabs her shoulder. The sheet turns over, and her naked breasts are revealed. This is followed by shots of the electric light on the ceiling, the monitor screen showing the cardiac rate, a droplet pouch, and the locked door knob, and it is accompanied by the sound of repeated shallow and brief breaths. When the breaths stop, there is a sharp groaning sound, and Shinji's palm is covered with white cum. This act of masturbation is one of the most critical scenes in voice acting history because of the challenge it posed to an actress voicing boys. Ogata controlled her breath skillfully and conveyed the physical immediacy of adolescent Shinji. One Japanese female viewer commented:

First, I was astonished by Shinji's masturbation, it was too realistic. But later, I understood this scene was necessary to depict his vulnerability. Driven by fear and cowardly as he is, he implored Asuka for help. ${ }^{13}$

This indicates the degree to which Ogata embodied Shinji, namely, up to his sexual arousal. With her performance of the angst-filled adolescent boy, she innovatively expanded the scope of voice acting in boy roles. This gave rise to a whole new trend, represented, for example, by Mitsuki Saiga, who debuted as a voice actress in I998. She has performed late-teen boys in dark, sexual and violent stories like Kyōsuke Date in The Soul Taker (200I) and appeared also in a game with sexual scenes and an NC-I7 rating aimed at male players, Ko ko ro ... voice ban (200I). Paratextually, she has presented herself in the media as a tall, thin person with short hair, always wearing masculine attire. Saiga utilizes her visual masculine appearance to reinforce the effect of cross-gender acting. Eventually, her stardom depends on the support from female fans who participate in playful communication with her. This case demonstrates that other voice actresses have followed the path trailblazed by Ogata in the I990s.
I3. Personal interview with the author on 20 July 2019. 


\section{Conclusion}

Ogata's performance in EVA was groundbreaking, but there were more factors involved than just talent. First, anime had matured as a young-adult media with an increasing interest in voice actors. Second, this interest was boosted by newly launched anime magazines, where the voice actors' bodies became visible in photos. Third, voice actors responded proactively to fans' demands, expectations and engagement, gaining star personae that went beyond characters of their own performance and construction. In an environment where these factors met, Ogata articulated the discrepancy between her characters and herself to the audience, and she embodied it as her star persona with the support of her fans. Consequently, she was able to endow a tangible, even sexual, presence to the anime characters. As such, she subverted long-standing conventions of voice acting in anime to create a new form. Her performance and multilayered stardom based on the interaction with her fans deserves to be counted as one of the acoustic achievements of EVA in the r99os.

Twenty-five years have passed since Ogata gained fame and popularity. Today, the popularity of voice actresses is utilized differently in idol-themed anime, works that narrate the life and dreams of idol protagonists and generate profits by means of live shows that display voice actors' visual similarity with their young and beautiful characters. ${ }^{14}$ Under these conditions that require visual coincidence between the voice actresses and the characters, EVA assumes a new critical meaning, because Ogata's stardom went in the opposite direction, that is, beyond visual similarity. Her innovation still calls for exploring the unexhau-

I4. The huge commercial success of Love Live! (since 2010) demonstrates that live shows by voice actresses in the role of characters is beneficial for the anime industry. The market for live entertainment including concerts by voice actors has purportedly expanded 2.5 times from 2013 to 2017 (Association of Japanese Animation 20I 8: 4). sted possibilities of voice acting and anime expression, which can be found in the deliberate discrepancy between the visual and the acoustic.

\section{References}

Animage. (I993a). On Air. Animage, I78, I I9. . ( (1993 b). Aoyama nichōme monogatari: Ogata-san wa seiyūkai no Takarasienne? Animage, I 86, I38-139. 
. (1994). Aoyama nichōme monogatari, vol.r 2: Ogata-san to futatsu no kokoro. Animage, I96, 64 .

. (1996a). Ogata to deito. Animage, 2 I I, 106-107.

. (1996b). Tokubetsu kikaku: Akemashite Best roo. Animage, 2I $2, \mathrm{I}-2$.

Anonymous. (2018). Personal Interview by the author, 25 November. . (2019). Personal Interview by the author, 20 July.

Association of Japanese Animation. (20I 8). Anime sangyō repōto 2018 samari ban. Retrieved from: https://aja.gr.jp/jigyou/chousa/sangyo _toukei

Azuma, S. (2019). Multilayered Performers: The Takarazuka Revue as Media. In J. Berndt, K. Nagaike and F. Ogi (eds.), Shōjo across Media: Exploring "Girl" Practice in Contemporary in Japan (pp. 26I-28I). Cham: Palgrave Macmillan.

Denison, R. (2017). Anime's Star Voices: Voice Actor (Seiyū) Performance and Stardom in Japan. In T. Whittaker \& S. Wright (Eds.), Locating the Voice in Film: Critical Approaches and Global Practices (pp. IOI-I I7). New York: Oxford University Press.

Doane, M. A. (1985). The Voice in the Cinema: The Articulation of Body and Space. In E. Weis \& J. Belton (Eds.), Film Sound: Theory and Practice (pp. I62-176). New York: Columbia University Press.

Dyer, R. (1998). Stars. London: British Film Institute.

Fujitsu, R. (2018). Seiyū ron: tsūshiteki, jisshōteki ichi kōsatsu. In M. Koyama \& A. Sugawa (Eds.), Anime kenkyū nyūmon ōyōhen: Anime o kiwameru I I no kotsu (pp. 93-I I7). Tokyo: Gendai shokan.

Hagino, K. (20I I). Interview. Yū Yü Hakusho 4 (pp. 305-3 Io). Tokyo: Shueisha.

Hikawa, R. (2000). Seikimatsu anime netsuron. Tokyo: Kinema Junpō-sha.

Hikawa, R. (ed.) (2013). Japanese Animation Guide: The History of Robot Anime. Tokyo: Mori Building Company, Ltd. https://mediag .bunka.go.jp/projects/project/images/JapaneseAnimationGuide.pdf 
Hill, M. L. (200I). Developing A Blind Understanding: A Feminist Revision of Radio Semiotics. In A. S. Weiss (Ed.), Experimental Sound \& Radio (pp. I07-I I 5). Cambridge, MA: The MIT Press.

Ishida, M. (2019). Deviating Voices: Representation of Female Characters and Feminist Readings in I990s Anime. IMAGE: Journal of Interdisciplinary Image Science (29), 22-37. Retrieved from: http:// www.gib.uni-tuebingen.de/own/journal/upload/22f86d 56 I 24584c64 6c53e82 I Iae9898.pdf

Jin, L. F. (2010). Nihon no animation ni okeru onsei no kinō: Ghost in the Shell/Kōkaku kidōtai, Shinseiki Evangelion, Sokyū no Fafner o chūshin ni. Hokkaidō daigaku daigakuin bungaku kenkyūka kenkyūronshū (IO), 235-25I.

Kawamura, T. (200I). VTR sangyō shi no kōsatsu to genzon shiryō no jōkyō. In Kokuritsu kagaku hakubutsukan (Ed.), Gijutsu no keitōteki chōsa hōkoku dai I shū. Tokyo: Kokuritsu kagaku hakubutsukan.

Kinoshita, K. (20I6). Personal Interview, 7 December.

Kobayashi, S. (2015). Seiyū shiron: "Anime Boom” ni miru shokugyō seiyū no tenkanten. Animēshon kenkyū, I6(2), 3-14.

Masuda, H. (2007). Anime Bujinesu ga wakaru. Tokyo: NTT Shippan.

Nakatani, T. (I982). Yamato fivā, yomigaeru Uchūsenkan Yamato. In K. Ikeda (Ed.), Anime daisuki Yamato kara Gundam e (pp. 87-II7). Tokyo: Tokuma Shoten.

\& Kushino, A. (1982). Uchūsenkan Yamato Hasshinsu!. In K. Ikeda (Ed.), Anime daisuki Yamato kara Gundam e (pp.23-50). Tokyo: Tokuma Shoten.

Nozawa, M., \& Hirano, F. (20 I6). Lejendo seiyū interview: Nozawa Masako $\times$ Hirano Fumi, Kōhen. Otocoto. Retrieved from: https:// otocoto.jp/interview/nozawaoo2/

Ogata, M. (I997). SAY YOU HISTORY. Animage, 223, 50-52.

Ōtsuka, E. (20I6). Nikai no jünin to sono jidai: Tenkeiki no sabukaruchā shibi. Tokyo: Seikaisha shinsho.

Shimizu, M. (20 I 5). Tetsuwan Atomu to ikite: Seiyū ga kataru anime no sekai. Saitama: Saitama shuppankai. 
Takeuchi, N. (I994a). Bishōjo senshi Sailor Moon 7. Tokyo: Kodansha. . (1994b). Bishōjo senshi Sailor Moon 8. Tokyo: Kodansha.

Tsugata, N. (20I I). Anime no rekishi. In M. Takahashi and N. Tsugata (eds.), Anime gaku (pp. 24-44). Tokyo: NTT Shuppan.

Tvtropes (2019). Children Voicing Children in Triva/Neon Genesis Evangelion. Retrieved from: https://tvtropes.org/pmwiki/pmwiki.php /Trivia/NeonGenesisEvangelion

Yoshida, N. (20I7). Zasshi bunka to sengo nihon shakai. In Noriaki Yoshida (ed.), Zasshi media no bunkashi: Henbō suru sengo paradaimu, zōhoban (pp. го-38). Tokyo: Shinwasha. 